\title{
Effectiveness of the Microcredit Program in Enhancing Micro-Enterprise Entrepreneurs' Income in Selangor
}

\author{
Fatin Najiha M. Tammili ${ }^{1}$, Zainalabidin Mohamed $^{1} \&$ Rika Terano $^{2}$ \\ ${ }^{1}$ Dept. of Agribusiness and Bioresource Economics, Faculty of Agriculture, University Putra Malaysia, Malaysia \\ ${ }^{2}$ Faculty of Business Administration, Nagasaki University, Japan \\ Correspondence: Fatin Najiha M.Tammili. Tel: 60-10-235-9504. E-mail: fatinnajihamtammili@gmail.com
}

Received: September 25, 2017

doi:10.5539/ass.v14n1p71

\author{
Accepted: October 19, 2017 \\ Online Published: December 27, 2017 \\ URL: https://doi.org/10.5539/ass.v14n1p71
}

\begin{abstract}
Poverty has been one of the pressing issues in developing countries like Malaysia. Amanah Ikhtiar Malaysia (AIM) was the first microcredit institution and one of the dominant players contributing to the poverty eradication in Malaysia through the provision of microcredit to the poor. Thus, the study aimed to investigate the effectiveness of the microcredit program on poverty eradication as experienced by AIM microcredit recipients in Selangor. Systematic random sampling was conducted to sample 326 Sahabat (from this point onwards the AIM microcredit recipients will be known as Sahabat) from February to April 2016. Descriptive analysis and multiple regression were used to analyse the data distribution and relationship between the dependent variable as measured by income-investment ratio and independent variables represented by socio-demographic as well as other related variables necessary to achieve the study objective. The findings of the study show that most of Sahabat were married (95.7 percent) and have secondary educated ( 72.7 percent). In terms of income distribution, most Sahabat earn less than RM1,500.00. Nevertheless, all Sahabat showed positive income changes after receiving different microcredit program schemes from AIM. Multiple regression analysis have identified two variables which are the family workers and hired workers where both significantly influenced the income-investment ratio after joining the microcredit program. This study affirmed the effectiveness of the AIM program in poverty eradication among the poor. AIM also plays an important role in meeting the financial needs of Sahabat which is necessary to enhance their microenterprises.
\end{abstract}

Keywords: microcredit, income, poor, income-investment ratio

\section{Introduction}

Poverty eradication continues to be one of the objectives of the country's developmental policy. Under the Tenth Malaysian Plan (2011-2015), the Government launched the National Transformation Policy (NTP) through the New Economic Model and sets the goal of moving the country into a high-income economy. This transformation is supported by the Economic Transformation Programmes and Government Transformation Programmes which focus on eradicating poverty and improving the living standard of Malaysians. Microcredit has become a prominent tool for poverty alleviation program in Malaysia and in most developing countries as well.

Thus in 1987 through the hands of Professor Muhammad Yunus, the most successful replication of the Grameen Bank of Bangladesh was established in Malaysia known as the Amanah Ikhtiar Malaysia (AIM) with the aim to reduce poverty. AIM was established under the Trustee Incorporation Act 258, 1987 to institutionalize an action research project carried out by the Centre for Policy Research of University Science Malaysia (USM), sponsored by the Asia and Pacific Development Centre (APDC), Islamic Economic Development Foundation of Malaysia (YAPEIM), and Selangor State Government where the outcome of the project was very encouraging and created a positive impact on the well-being of microcredit borrowers. Thus the main objectives of AIM are to reduce poverty among the poor and low-income households; to provide microcredit to fund activities that can improve income; and to provide funding, guidance, and training to the entrepreneurs from poor and low-income families (Gibbon et al., 1990).

As the years go by, AIM not only gives microcredit to help the poor generate income via creating small businesses and other economic activities but today, the microcredit schemes offered by AIM can be divided into two categories. The first is microcredit for economic activities, which are i-Mesra, i-Srikandi and i-Wibawa, and the second is for non-economic activities, which are i-Sejahtera, i-Bestari, i-Penyayang, and i-Emas (AIM, 2016). 
Each microcredit scheme has their own prescriptions, guidelines, regulations and amount to be disbursed. With these loan schemes, it is hoped that the poor can set up not only small businesses to increase their income and improve their well-being but also increase their standard of living. Since it's inception some 29 years ago as a private trust, AIM has disbursed about RM 15,097,046,687 as of April 2016, funded 382,178 active borrowers across 156 branches nationwide (AIM, 2016). Today, AIM is the leading microcredit institution and considered as the pioneer in Malaysia. Hence, AIM only selects Sahabat with household income below RM3,855 and per capita income below RM828 per month as prescribed by the poverty line index (PLI).

Microcredit has been recognised as a cost-effective way of combating poverty and developing the institutional capacity of the financial system to lend money to the poor (Jonathan Morduch, 2000). According to Christen et al., (2003), microfinance refers to the stipulation service for the poor and lower income citizens to assist them in obtaining microcredit service that includes the provision of regulated low income such as housing microfinance, pensions, savings and transfer services, micro-insurance and remittance management. The types of financial services that can be considered microfinance include loans, deposit facilities, and instruments for the transfer of funds to marginal clienteles, especially to the poor (Gonzalez-Vega, 1998). Microcredit can be recognised as an essential socio-economic and financial mechanism for poverty alleviation, promoting entrepreneurial development, and increasing the profile of disadvantaged people in numerous countries around the world (Hossain et al., 2012). Microfinance also serves to alleviate rural livelihoods and urban poor through the creation of entrepreneurship opportunities that encourage the elimination of unemployment by developing potential businesses based on their interest and skills. Furthermore, Microcredit serves as small loans to poor people for self-employment projects that can generate income and allows them to take care of themselves and their families (Bank for the Poor: Garmeen Bank, 2014; International Year of Microcredit, 2015).

In Malaysia, Hamdino (2012) went further to indicate that married couples who are between the ages of 41-50 years of age seem to be the most successful microcredit recipients compared to single or younger recipients. This could be due to their experiences and good team spirit as they work together to improve their business. Similar study to Hamdino (2012), Terano et al. (2015) also reported that married couples were more effective in handling their microcredit. There were positive changes in their earning ability, the ability to pay back on schedule, improved well-being and livelihood. M. Zaini Omar et al. (2012) reported that AIM microcredit programme has a positive impact on household income and poverty alleviation in Kedah, especially among married participants who are between the ages of 40-49 years. Thus, it can be concluded that AIM has both economic and social impacts on its participants. Similar finding was also reported by Haryanti et al. (2012). According to Sayed Samer et al. (2015), the older members enjoy higher household income compared to the new ones and this is because they have spent over 3 years in the scheme and attended more business training. Thus the aim of this paper is to determine the factors that could enhanced the income of the AIM microcredit recipients by analysing the income-investment ratio among Sahabat.

\section{Material and Method}

\subsection{Sample and Questionnaire}

Systematic random sampling was used to select 326 Sahabat of AIM microcredit program recipients based on the information collected from AIM headquarters in Kuala Lumpur. There are 156 AIM branches all over Malaysia but this study will concentrate on 6 branches in the state of Selangor Darul Ehsan. The six branches were; Hulu Langat, Kuala Selangor, Barat Laut Selangor, Gombak, Selayang, Shah Alam and Klang to conduct face to face interview.

A list of targeted Sahabat which are agro-based and center meetings were obtained from AIM branches mentioned earlier. Systematic random sampling was performed in each meeting center to select and interview Sahabat that met the criteria for inclusion in the study. The center meetings selected were community halls, council housing, mosque, and flat house.

The questionnaire was designed to include open and close-ended questions specifically to achieve the objectives of the study. The questionnaire is divided into two parts: (a) demographic and loan profiles and (b) information in terms of the effectiveness of the microcredit. The survey was conducted from February to April 2016.

\subsection{Research Hypothesis}

The conceptual framework of the study was based on Figure 1. The basic aim of microcredit is to increase the income of the Sahabat so they can be better off than what they were. Involvement in the microcredit program serves as an important avenue for extending the size of a microenterprise or starting a new business. Thus a good business management is another factor for microcredit recipients in pursuing the Sahabat objective. The number 
of employees, either from family or hired workers is another factor indicating the extend of their business. The demographic profiles describe the Sahabat characteristics which can also influence the success of the microcredit they've taken. The revealed influential determinant which is the income-investment ratio was used as a proxy in successful business by Sahabat of AIM. (Income-Investment Ratio= Total income / Total Investment). The total income and investment (microcredit from AIM) was obtained for a 2 year period i.e. 2014 and 2015. The hypothesis concerned on income-investment ratio is been formulated as follows:

Hypothesis: There is no significant relationship between experience, time per day, entrepreneurial training, amount of loan, family workers, hired workers, marital status, education level and income-investment ratio.

\subsection{Pilot Study}

The effectiveness of the research tool in measuring required outcome can be tested through a pilot study. In order to evaluate the viability of the questionnaire, a sample size of 68 was used for the pilot study. The Cronbach's alpha was employed to measure the reliability of the 15 variables selected. Cronbach's alpha was value greater than 0.50 means that there is acceptable Develis (2003) among the theory an factor analysis is fit to be used for the study. The Cronbach's alpha value for the entire statements is 0.853 , indicating very high reliability.

\subsection{Method of Analysis}

Firstly, descriptive analysis was conducted to show the Sahabat demographic profiles variables. Secondly, multiple regression analysis was conducted to determine the effect of microcredit financing on the recipients' income. Income in this case was represented by income-investment ratio as the dependent variable while other variables such as borrowers' demographic profile, experience (years), time per day working on business (hours), amount of loan, family workers, and hired workers were the independent variables.

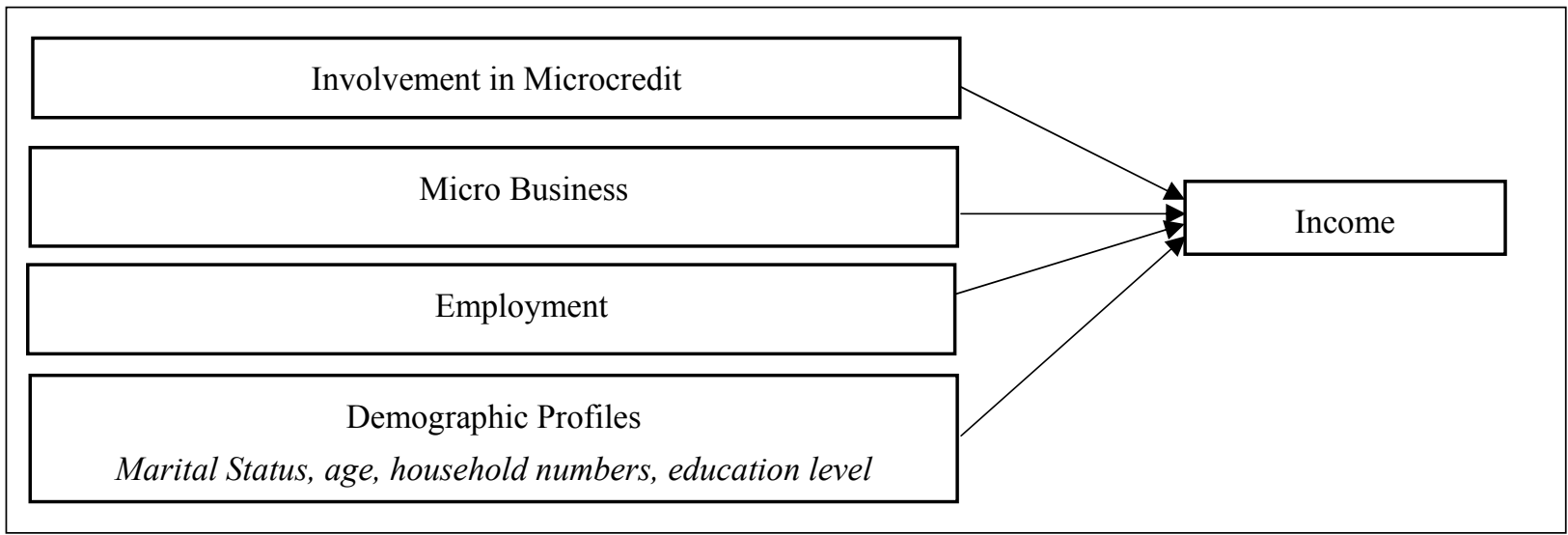

Figure 1. Conceptual Framework

The regression model used can be specified as follows:

$$
\mathrm{Y}=\mathrm{a}+\mathrm{b}_{1} \mathrm{X}_{1}+\mathrm{b}_{2} \mathrm{X}_{2}+\mathrm{b}_{3} \mathrm{X}_{3}+\mathrm{b}_{4} \mathrm{X}_{4}+\mathrm{e} ;
$$

Where:

$\mathrm{Y}$ is income-investment ratio of the microcredit program average of 2 years (2014-2015)

$\mathrm{X}_{1}$ is marital status; $0=$ single, and $1=$ married

$\mathrm{X}_{2}$ is a dummy for education level; $0=$ primary and secondary, and $1=$ tertiary

$\mathrm{X}_{3}$ is a dummy for experience; $0=$ less than 10 , and $1=$ more than 11

$\mathrm{X}_{4}$ is a dummy for time per day working on the business; $0=$ less than 8 , and $1=$ more than 9

$\mathrm{X}_{5}$ is entrepreneurial training; $0=$ not involved, and $1=$ involved

$\mathrm{X}_{6}$ is a dummy for amount of loan; $0=$ below RM15,000, and $1=$ above RM15,001

$\mathrm{X}_{7}$ is family worker; $0=$ do not have, and $1=$ have

$\mathrm{X}_{8}$ is hired worker; $0=$ do not have, and $1=$ have

\section{Results and Discussion}

\subsection{Descriptive Analysis}

The distribution of the socio-demographic profile of AIM Sahabat is shown in Table 1. Most of the AIM Sahabat 
were married (95.7\%), majority have at least a secondary education $(72.7 \%)$, followed by primary education $(16.3 \%)$ and tertiary education (11.0\%). Similarly to Hamdino (2012), Terano et al. (2015) also reported that married couples and secondary educated were more effective in handling the microcredit. The largest age group is between $41-50$ years old (35.6\%). About $52.1 \%$ of Sahabat have between 1-5 people in their household, followed by 6-10 people (45.7\%) and 11-15 people (2.10\%). About 68 Sahabat (20.9\%) earn below RM1500 per month, 116 Sahabat (35.6\%) earn between RM1,501-RM2,500 per month, 80 Sahabat (24.5\%) earn between RM2,501-RM3,500 per month, 31 Sahabat (9.5\%) earn between RM3,501-RM4,500 per month and 31 Sahabat (9.5\%) earn above RM4,501 per month. Moreover, most of the Sahabat $(53.7 \%)$ are engaged in food stall business and $41.7 \%$ of them have less than 5 years of experience.

Table 1. Demographic Profile of Sahabat, N=326 Female

\begin{tabular}{|c|c|c|}
\hline Characteristics & Frequency & Percentage \\
\hline \multicolumn{3}{|l|}{ Marital Status } \\
\hline Single & 14 & 4.30 \\
\hline Married & 312 & 95.7 \\
\hline \multicolumn{3}{|l|}{ Educational Level } \\
\hline Primary & 53 & 16.3 \\
\hline Secondary & 237 & 72.7 \\
\hline Tertiary & 36 & 11.0 \\
\hline \multicolumn{3}{|l|}{ Age } \\
\hline Below 30 & 25 & 7.70 \\
\hline $31-40$ & 69 & 21.2 \\
\hline $41-50$ & 116 & 35.6 \\
\hline $51-60$ & 95 & 29.1 \\
\hline Above 61 & 21 & 6.40 \\
\hline \multicolumn{3}{|l|}{ Household Number } \\
\hline $1-5$ & 170 & 52.2 \\
\hline $6-10$ & 149 & 45.7 \\
\hline $11-15$ & 7 & 2.10 \\
\hline \multicolumn{3}{|c|}{ Income Distribution (average for 2014-2015 period) } \\
\hline Below RM1,500 & 68 & 20.9 \\
\hline RM1,501-RM2,500 & 116 & 35.6 \\
\hline RM2,501-RM3,500 & 80 & 24.5 \\
\hline RM3,501-RM4,500 & 31 & 9.5 \\
\hline Above RM4,501 & 31 & 9.5 \\
\hline \multicolumn{3}{|l|}{ Type of business } \\
\hline Retail & 61 & 18.7 \\
\hline Processing and Manufacturing & 25 & 7.70 \\
\hline Fish, Livestock and Crop cultivation & 65 & 19.9 \\
\hline Food Stall business & 175 & 53.7 \\
\hline \multicolumn{3}{|l|}{ Experience in Business } \\
\hline Below 5 years & 136 & 41.7 \\
\hline $6-10$ years & 102 & 31.3 \\
\hline $11-15$ years & 38 & 11.6 \\
\hline $16-20$ years & 25 & 7.70 \\
\hline Above 21 years & 25 & 7.70 \\
\hline
\end{tabular}

Source : Own survey 2016

\subsection{Income-Investment Ratio}

This study aimed to determine the effect of microcredit financing on the recipients' income. To achieve this, we need to estimate the income-investment ratio. Thus, the income-investment ratio was derived by dividing the total income by the total investment (Mizanur et al., 2010 and Norma et al., 2010). The result shows that the income-investment ratio averaged 4.062. This indicates that the microenterprise activities carried out by the 
Sahabat are successful in generating income. Table 2 shows the Income-investment ratio distribution and also the range of income investment ratio based on the range based on very low and very high ratio. As can be seen in Table 3, the frequency distribution of the income-investment ratio also reveals that some of the Sahabat are not doing very well which is noted by the low value of their income-investment ratio (minimum ratio of 1.07).

The general equation of the income investment ratio is as shown below:

Income-Investment Ratio $=$ Total Income $/$ Total Investment

Income $=$ for two years (2014 to 2015)

Loan $=$ for two years (2014 to 2015)

Table 2. Income-Investment Ratio

\begin{tabular}{lll}
\hline Income-Investment Ratio measure & Income-Investment Ratio value \\
\hline Mean & 4.062 & \\
Median & 3.963 & \\
Standard Deviation & 1.515 & \\
Minimum & 1.07 & \\
Maximum & 7.30 & Frequency Distribution (Sahabat) \\
Range & & 17 \\
Very Low Ratio & $<1.99$ & 146 \\
Low Ratio & $2.00-3.99$ & 112 \\
High Ratio & $4.00-5.99$ & 51 \\
Very High Ratio & $>6.00$ & \\
\hline
\end{tabular}

Source : Own survey 2016

As shown in Table 2 above, about 17 Sahabat (5.2 percent) were categorised under "very low ratio" based on the results of their two years income-investment ratio from 2014 to 2015. Also, 146 Sahabat (44.8 percent) were categorised under low ratio, while 112 Sahabat (34.4 percent) and 51 Sahabat (15.6 percent) were categorised under high ratio and very high ratio respectively.

Furthermore, Table 2 shows that the minimum income-investment ratio is 1.07 , indicating that some Sahabat did not perform well in their microenterprises. The incidence of very low and low ratio categories could be due to the low educational background of most of the Sahabat (primary and secondary education). It could also be due to the low return on investment associated with the first scheme (i-Mesra loan) as the new Sahabat might still be lacking the necessary experience. The first financing is RM3,000 and can increase to a maximum of RM10,000 as stipulated in the i-Mesra loan scheme. Other than that, Sahabat also engages in small enterprises like small food stall businesses such as junk food, nasi lemak, local fruits, drink stalls and others. The result also shows that the maximum income-investment ratio is 7.30 indicating that some Sahabat perform well in their microenterprises and generating high income. High income generated by these Sahabat is due to larger businesses such as chicken rearing, retail business, as well as processing and packaging of chips. Besides that, the Sahabat can access the second scheme (i-Srikandi) offered to those who already took the i-Mesra scheme.

\subsection{Multiple Regression}

Before the multiple regression analysis was conducted, some tests were carried out to determine the reliability of the data collected so that further analysis can be conducted. Table 3 is based on Tolerance greater than 0.2 and Variance Inflation Factor (VIF) less than 5. This indicates no multicollinearity problem since both values are within the acceptable range. Table 4 shows the result of the Collinearity Statistics.

The multiple regression was estimated to determine the relationship between the dependent and independent variables as discussed earlier in the methodology section. The multiple linear regression model was applied to determine the effect of AIM program on the income of the Sahabat. The coefficient of determination $\left(\mathrm{R}^{2}\right)$ is 0.096, indicating that the factors (variables) in the model reflects $9.6 \%$ in the income-investment ratio of the Sahabat. The F-value is $4.206(\mathrm{P}<0.00)$ indicating significant overall relationship between dependent variable and all the independent variables. These findings correspond with the findings of Hamdino (2012), G. Maggiano (2006), Rosman et al., (2015) as they also generate low $\mathrm{R}^{2}$ in their respective studies. The finding shows that two variables (family workers and hired workers) out of the eight variables are positive and statistically significant (Table 4).

The number of family workers and hired workers have significant positive relationship with the 
income-investment ratio. This indicates that the number of workers play an important role in the income generating activities and can be pivotal in moving the enterprises forward.

Table 3. Collinearity Statistics

\begin{tabular}{ccc}
\hline & Collinearity Statistics & VIF \\
\hline Marital status & Tolerance & 1.041 \\
Education Level & 0.961 & 1.038 \\
Experience & 0.964 & 1.048 \\
Time per day & 0.955 & 1.006 \\
Entrepreneurial Training & 0.994 & 1.013 \\
Amount of Loan & 0.987 & 1.081 \\
Family workers & 0.925 & 1.036 \\
Hired workers & 0.965 & 1.071 \\
\hline
\end{tabular}

Source: Own survey 2016

Note: Tolerance $>0.2$; Variance Inflation Factor $<5$

Table 4. Multiple linear regression coefficients of the factors contributing to the income of Sahabat

\begin{tabular}{ccccc}
\hline Dependent variable & Independent variable & Unstandardized Coefficient (Beta) & T-value & Sig. \\
\hline Income- Investment Ratio & Constant & 3.833 & 7.271 & 0.000 \\
& Marital Status & -0.365 & -0.899 & 0.369 \\
& Education Level & -0.031 & -0.119 & 0.906 \\
& Experience & 0.033 & 0.179 & 0.858 \\
& Time per day & 0.149 & 0.846 & 0.398 \\
& Entrepreneurial Training & -0.173 & -1.061 & 0.289 \\
& Amount of Loan & -0.157 & -0.933 & 0.352 \\
& Family workers & 0.693 & 3.741 & $0.000^{* * *}$ \\
& Hired workers & 0.827 & 4.163 & $0.000^{* * *}$ \\
\hline
\end{tabular}

Source: Own survey 2016

Note: $* * *$ Statistically significant at the 0.01 level $* *$ at the 0.05 level and $*$ at the 0.1 level

\section{Limitations and Suggestions for Future Research}

The present study is subjected to a number of limitations. Although this study achieved its aim, there were some unavoidable limitations. The study focused on the Sahabat in Selangor and could not afford to sample the whole Malaysia. However, gaining access to such a population size would prove difficult and beyond the time and budget constraints of the study. In addition, the study is related to the Sahabat demographic profile and the acquired data depends on the cooperation and honesty in giving accurate information especially accuracy of the reported income and investment level. Further study, microcredit loan should be measured based on the level of its effectiveness across different household income.

\section{Conclusion}

AIM plays an important role in meeting the financial needs of the Sahabat such as the provision of credits for enhancing their microenterprises and also serves as an effective tool for poverty eradication. This study highlights the effectiveness of the AIM program towards increasing income among microenterprise entrepreneurs. The study explores the demographic profile and Sahabat characteristics with regards to the total income. The result showed that majority of the Sahabat are married, attained secondary education, aged between 41-50 years old and involved in the food stall business. All these characteristics significantly contribute towards the increased income.

AIM microcredit program provides an opportunity for the Sahabat to increase the total income derived from their microenterprises or business. It serves as a driving force for the poor and also important in reducing their poverty level. Family workers and hired workers have positive influences on income-investment ratio after joining the AIM microcredit program. Most of the Sahabat perceived that their lives have improved since they become a member of the AIM program. Hence, AIM should find a way to increase income by improving the sustainability and growth. This is important as it has higher probabilities of improving family well-being and graduating Sahabat above the poverty line income. 


\section{Acknowledgments}

This research is funded by the Universiti Putra Malaysia (UPM) and under the Geran Universiti Putra Malaysia. The authors would like to thanks UPM for sponsoring this research from February to April 2016.

\section{References}

Al-shahmi, S. S. A., Majid, I. B. A., Hamid, M. S. R. B., \& Rashid, N. A. (2014). Conceptual Framework: the Role of Malaysian Microfinance on the Wellbeing of Users' Services from the Perspective of (AIM) and (TEKUN). In University 4th International Islamic Banking and Finance Conference. Kuala Lumpur (pp. 13-14).

Amanah Ikhtiar Malaysia. (2016). Schemes of Amanah Ikhtiar Malaysia. Retrieved from http://www.aim.gov.my/ cms/index.html.

Babu M, M. (2016). Some Determinants of Changes in the Real Income of Microfinance Programme Participating Households in Kerala. International Journal of Rural Management, 12(1), 51-71.

Christen, RP, Lyman, TR, \& Rosenberg, R. (2003). Microfinance Consensus Guidelines; guiding principles on regulation and supervision of microfinance. USA: Washington.

DeVellis R.F. (2003). Scale Development: Theory and Applications. Sage, Thousand Oaks, CA, USA.

Economic Planning Unit (11MP). (2016). Eleven Malaysian Plan. National Economic Policy. Retrieved from http://rmk11.epu.gov.my/book/bm/Rancangan-Malaysia-Kesebelas/Buku\%20RMKe-11.pdf.

Economic Planning Unit (11MP). (2016). Eleven Malaysian Plan. National Development Policy. Retrieved from http://rmk11.epu.gov.my/book/bm/Rancangan-Malaysia-Kesebelas/Buku\%20RMKe-11.pdf.

Economic Planning Unit (11MP). (2016). Eleven Malaysian Plan. National Vision Policy. Retrieved from http://rmk11.epu.gov.my/book/bm/Rancangan-Malaysia-Kesebelas/Buku\%20RMKe-11.pdf.

Economic Planning Unit (11MP). (2016). Eleven Malaysian Plan. National Transformation Policy. Retrieved from http://rmk11.epu.gov.my/book/bm/Rancangan-Malaysia-Kesebelas/Buku\%20RMKe-11.pdf

Gibbons, D. S., \& Sukor, K. (1991). Annual report: Banking on the rural poor in Peninsular Malaysia. Penang, Malaysia: Amanah Ikhtiar Malaysia.

Gonzalez-Vega, C. (1998). Microfinance: broader achievements and new challenges. Economics and Sociology Occasional Paper No. 2518. The Ohio State University: Electric Bulletin.

Grameen Bank. (2014). Bank for the Poor. Retrieved from http://www.grameen.com/

Hamdan, H., Othman, P., \& WSW, H. (2012). Is microfinance program in Malaysia really effective in helping the poor. World Review of Business Research, 2(1), 79-97.

Hossain, M. (1988). Credit for alleviation of rural poverty: The Grameen Bank in Bangladesh (Vol. 65). Intl Food Policy Res Inst.

International Year of Microcredit. (2015). Retrieved from http://www.yearofmicrocredit.org/pages/whyayear/wh yayear_aboutmicrofinance. asp

Jahan, I., \& Mamun-ur-Rashid, M (2015). Socio-economic Impact of IBBL Microfinance on Rural Women in a Selected District of Bangladesh.

Maggiano, G. (2006). The Impact of Rural Microfinance: Measuring Economic, Social and Spiritual Development in Kabale, Uganda (Doctoral dissertation, Georgetown University).

Mahmood, R., Zahari, A. S. M., \& Zin, S. M. (2015). The microcredit-business performance relationship: Program delivery services as mediator. Mediterranean Journal of Social Sciences, 6(6 S2), 691.

Mizanur Rahman, M., \& Ahmad, F. (2010). Impact of microfinance of IBBL on the rural poor's livelihood in Bangladesh: an empirical study. International journal of Islamic and Middle Eastern finance and management, 3(2), 168-190.

Morduch, J. (2000). The microfinance schism. World development, 28(4), 617-629.

Muthoni, M. P. (2016). Assessing Institutional Characteristics on Microcredit Default in Kenya: A Comparative Analysis of Microfinance Institutions and Financial Intermediaries. J. of Edu. \& Practice, 7(18), 178-198.

Nor, N. H. M., Rashid, S. N. M., Nawawi, R., \& Mohd, F. (2012). Women Enterprenuership in Micro Credit Performance: The Preliminary Study in Kelantan. In Knowledge Management International Conference 
(KMICe) (pp. 724-729).

Norma Md. Saad. (2011). Selecting High-Income Generating Activities for Micro-Entrepreneurs: The Case Study of Amanah Ikhtiar Malaysia. International Journal of Humanities and Social Sciences, 1(5), 258-264.

Omar, M. Z., Noor, C. S. M., \& Dahalan, N. (2012). The economic performance of the Amanah Ikhtiar Malaysia rural microcredit programme: A case study in Kedah. World, 2(5).

Saad, N. M., \& Duasa, J. (2010). Determinants of Economic Performance of Micro-Credit Client and Prospect of Islamic Microfinance in Malaysia. ISRA International Journal of Islamic Finance, 2(1), 113-130.

Terano, R., Mohamed, Z., \& Jusri, J. H. H. (2015). Effectiveness of microcredit program and determinants of income among small business entrepreneurs in Malaysia. J. of Global Entrepreneurship Res., 5(1), 1-14.

\section{Appendix A}

Instruction: Please tick $(\sqrt{ })$ in the appropriated box and fill in the blank

1. Marital Status

Single

Married

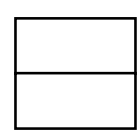

2. Education Level

Primary School

Secondary School

STPM

Diploma

Degree

3. Number of Households(include Sahabat) :

4. Age (Sahabat) :

5. Income Distribution : RM

6. What kind of business that you are involved with microcredit ?

7. How long you are experience in this business ? years

8. How much time per day/ working you for their business ? hour

9. How much you invest in microcredit loan?

$\mathrm{RM}$

10. Have you take the family workers in their business?

Yes

No

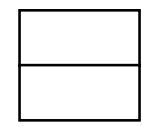

11. Have you take the hired workers in their business ?

Yes

No

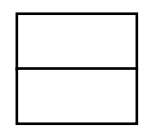

12. Have you involved in entrepreneurial training in microcredit program?

Yes

No

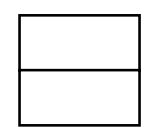

\section{Copyrights}

Copyright for this article is retained by the author(s), with first publication rights granted to the journal.

This is an open-access article distributed under the terms and conditions of the Creative Commons Attribution license (http://creativecommons.org/licenses/by/4.0/). 